\title{
COSTS OF CONTINUOUS SUBCUTANEOUS INSULIN INFUSION AND MULTIPLE-DOSE INSULIN THERAPIES FOR TYPE 1 DIABETES MELLITUS: A REVIEW OF HEALTH ECONOMICS STUDIES
}

\section{Luis Eduardo Galvao Martinsa, Ana Lucia Domingues Nevesa*, Fernanda Silva Tenórioa, Tatiana Sousa Cunha}

Universidade Federal de São Paulo - UNIFESPa

E-mail: ana.neves@unifesp.br

\begin{abstract}
Multiple Doses of Insulin and Continuous Subcutaneous Insulin Infusion are the most used technologies for the treatment of Type 1 Diabetes Mellitus due to the favorable impact in glycemic control. The objective was to evaluate the two forms of Type 1 Diabetes Mellitus treatment through cost-effectiveness, cost-benefit, and cost-utility. A bibliographic search was carried out, including nine databases: Institute of Electrical and Electronic Engineers, International Society for Pharmacoeconomics and Outcomes Research, Scientific Eletronic Library, Medline, Ovid, Springer, Compendex, Scopus and Inspec. The search was limited to articles in English, Portuguese, and Spanish published during the last twenty-five years, and a total of 42 studies were included in the research. The costs associated with the use of the Continuous Subcutaneous Insulin Infusion are higher, however, associations were found between its use and the improvement in the HbA1c levels and the year of life adjusted to quality, such as reducing the chronic fear of severe hypoglycemia, greater flexibility in lifestyle and participation in social and physical activities, in addition reducing glycemic oscillations and episodes of hypoglycemia. Therefore, the clinical benefits of Continuous Subcutaneous Insulin Infusion are evident, and it is important to mention that studies show that the higher costs that treatment may be partially mitigated by a reduction of the expenses in treating T1DM-related complications, and the additional costs can be recovered within few years.
\end{abstract}

Keyword: Cost-effectiveness; Cost-benefit; Cost-utility. 


\section{INTRODUCTION}

Diabetes Mellitus (DM) is considered a global epidemic disease, representing a significant challenge for healthcare systems (WORLD HEALTH ORGANIZATION. DIABETES., 2020). According to the International Diabetes Federation (IDF), the number of people living with DM has grown by more than $60 \%$ in the last ten years, the equivalent to 463 million in the world, reaching up to 700 million by 2045 (IDF, 2019).

Specifically, Type 1 Diabetes Mellitus (T1DM) is caused by an autoimmune reaction in which the insulin-producing beta cells of the pancreas are destroyed. As a result, the body produces small amounts or no insulin. T1DM is the primary cause of diabetes in childhood but can occur at any age and, at present, it cannot be prevented. The T1DM affects $10 \%$ of all diabetes worldwide; an estimated 1.1 million patients are children and teenagers under 20 year old (IDF, 2019).

It is estimated that the incidence of T1DM among children and adolescents is increasing, particularly in those under 15 years old (IDF, 2019), showing that those patients face a long period of chronic and progressive illness and complications. Among those, there are the acute complications, including hypoglycemia, hyperosmolar hyperglycemic condition, and diabetic ketoacidosis, and also the chronic complications, such as cardiovascular and peripheral vascular disease, retinopathy and neuropathy (IEZZI et al., 2014; LOEWEN and HAAS, 1991). The most frequent degenerative complications are acute myocardial infarction, peripheral arteriopathy, stroke, and microangiopathy (AMÉRICO and ROCHA, 2020; CORTEZ et al., 2015). However, it is well established that these complications of T1DM can be avoided when glycemic control is adequate (GOMES et al. 2018).

Several advances in the technology of T1DM treatment were necessary for the development of therapies facilitators for disease management. Multiple doses of insulin (MDI) and continuous subcutaneous insulin infusion (CSII) (RIBEIRO, MEB; L ROIO LIBERATORE JUNIOR and CUSTODIO and MARTINELLI JUNIOR, 2016) are the most widely used therapies for T1DM due to the favorable results on blood glucose control (BECK et al., 2019). In this sense, the study by the Research Group on Diabetes and Complications Control (DCCT) (NATHAN, 2014) showed that children with T1DM under CSII therapy showed improvement in glycemic control, reduction in severe hyperglycemia and number of hospitalizations due to diabetic ketoacidosis compared to MDI (OLIVEIRA et al., 2018; POLLARD et al., 2018). However, the costs of CSII therapy are high, representing three times the cost of MDI, and so, the number of diabetic patients using CSII is still small, especially in developing countries.

On the other hand, it is important to mention that the higher costs of CSII treatment may be partially mitigated by a reduction of the expenses in treating T1DM-related complications, and the additional costs can be recovered within three years (DAVID et al., 2012). Based on this, the context of public health studies state that decision-making on the best therapy for T1DM treatment should consider economic interventions in the procedure as a whole picture (MINISTRY OF HEALTH, 2014), based not only on the costs of treatment but also on the costs related to diabetes complications and on the impact on the patient's lives. So, health decision-makers will have information on the pros and cons of newly available technologies and assess whether they are worth sticking to (MINISTRY OF HEALTH, 2014).

Therefore, economic health assessment, a tool to assist the decision-making process on resource use, is valuable for comparing alternative action proposals (GÓMEZ-DANTÉS and FRENK, 2009; KOCH et al., 2009), such as the treatment of T1DM through CSII or MDI (POZZILLI et al., 2016). This type of assessment comprises formal analytical techniques, taking into consideration the invested resources, and the clinical results of each one (NUNES DA SILVA et al., 2016) to answer which therapy is the most indicated in terms of long- and short-term costs. Several studies have been published in recent years, making a cost-effectiveness analysis of treatment with CSII vs. MDI (DONLO et al., 2006); however, few have focused on CSII vs. MDI using more than one aspect of economic evaluation. Among the main types of economic evaluation, we have cost-benefit, cost-usefulness, and cost-benefit defined in Table 1. 
Table 1. Types and characteristics of the main economic health assessment techniques

\begin{tabular}{|c|c|c|c|c|}
\hline $\begin{array}{c}\text { Economic } \\
\text { Analyses Types }\end{array}$ & Cost & Health Outcomes & Advantage & Disadvantage \\
\hline Cost-Effectiveness & Monetary & $\begin{array}{l}\text { Days without seizures, } \\
\text { hypoglycemic graves, or } \\
\text { disability days avoided } \\
\text { other prevented diseases, } \\
\text { prevented hospitalizations, } \\
\text { several lives saved, and } \\
\text { years of life saved }\end{array}$ & $\begin{array}{l}\text { Uses concrete outcomes of } \\
\text { clinical practice; selects the } \\
\text { best option to obtain } \\
\text { efficiency }\end{array}$ & $\begin{array}{l}\text { Comparison of } \\
\text { studies is restricted } \\
\text { to one-dimensional } \\
\text { outcome common to } \\
\text { studies }\end{array}$ \\
\hline Cost-Utility & Monetary & $\begin{array}{l}\text { Quality-Adjusted Life } \\
\text { Years (QALY) } \\
\text { or Disability Adjusted Life } \\
\text { Years (DALY) }\end{array}$ & $\begin{array}{l}\text { Integrates gains in reducing } \\
\text { morbidity (quality) and } \\
\text { gains in reducing mortality } \\
\text { (years gained) }\end{array}$ & $\begin{array}{l}\text { Possible validation } \\
\text { problems of utility } \\
\text { measuring } \\
\text { instruments }\end{array}$ \\
\hline Cost-Benefit & Monetary & $\begin{array}{l}\text { Converted to monetary } \\
\text { value }\end{array}$ & $\begin{array}{l}\text { It allows comparison of } \\
\text { several studies since all are } \\
\text { measured in the same unit } \\
\text { value; comparison not only } \\
\text { between health } \\
\text { interventions but also } \\
\text { between other decision } \\
\text { areas }\end{array}$ & $\begin{array}{l}\text { A difficult task to } \\
\text { monetize health } \\
\text { outcomes }\end{array}$ \\
\hline
\end{tabular}

Due to the need to expand a discussion on all costs of treating T1DM with CSII or MDI, we sought to answer the research question "What are the costeffectiveness, cost-usefulness, and cost-benefit of using CSII and MDI in the treatment of T1DM?". To describe the costs of CSII therapy and MDI for treatment of disease we have a hypothesis that higher costs of treatment with CSII can be minimized by reducing costs in the treatment of complications related to T1DM. Therefore, this paper proposes to evaluate the CSII and MDI through the cost-effectiveness, cost-benefit, and cost-utility analyses for the treatment of T1DM, supporting decision-making, improving resource allocation, and prioritizing public health policies.

\section{MATERIAL AND METHODS}

We conducted a literature review in the areas of health and economics using nine databases: Institute of Electrical and Electronic Engineers (IEEE),
International Society for Pharmacoeconomics and Outcomes Research (Ispor), Scientific Eletronic Library (SciELO), Medline (via Pubmed), Ovid, Springer, Compendex, Scopus and Inspec from March to July 2019. The keywords were as follows: Costeffectiveness; Cost-benefit; Cost-utility; Insulin; Insulin infusion pump; Healthy economy; Type 1 Diabetes Mellitus. The research string used for each cost analysis data was as follows: ("Analyzes *" OR Data) AND ("insulin infusion system" OR "insulin pump" OR "infusion system" insulin") varying only the end of the research strategy, according to the specific analysis, as follows. For cost-benefit, we added the term: AND ("cost-benefit" OR "cost-benefit ratio" OR "cost benefit"); for cost-effectiveness, the following term has been added: AND ("cost-effectiveness" OR "costeffectiveness ratio" OR "cost effectiveness"); finally, for cost-utility, we added the terms: AND ("cost-utility" OR "cost-utility ratio" OR "cost utility"). The Figure 1 represents a flowchart of the described methodology. 
Figure 1. Flowchart of the data collection process in the SciELO, Compemdex, Ovid, Pubmed, Ispor, IEEE, Springer, Scopus, Inspec.

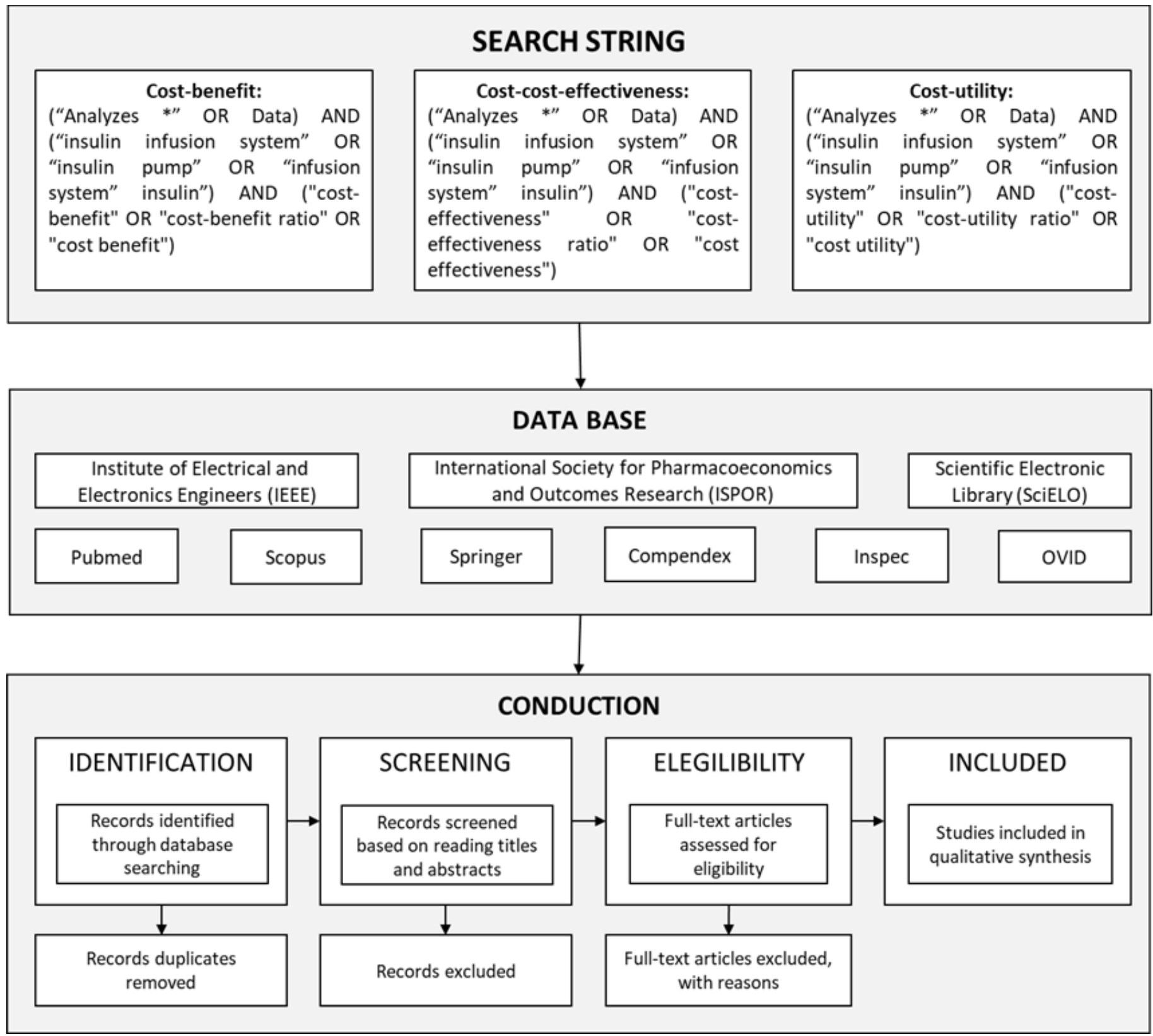

\section{Study selection and data extraction}

The entire process of searching, selecting, and extracting data from the items in this phase of the study was carried out in pairs. The search was limited to articles in English, Portuguese, and Spanish published during the last twenty-five years. Other inclusion criteria adopted for the selection of materials were studies that described the cost-benefit, cost-utility, and cost-effectiveness of using CSII and MDI therapies for T1DM. Methodologically inconsistent studies were excluded. The titles and abstracts of all identified articles were analyzed. Based on this, the abstracts were selected according to the objectives of the study, and, finally, the texts were read in full.

\section{Data storage and data analyses}

After selecting documents according to the object of study and reading the texts in full, an 
identification/storage system was created for each series of documents, according to the main characteristics: title of the article, name of authors, name of the scientific journal, year of publication, the aim of study, methods, means results and conclusion. To facilitate the analysis, data was organized in groups according to similarity, thematic relevance and chronological order, and tabulated in a Microsoft Excel® chart.

\section{RESULTS}

A total of 42 studies were included in the present work. The most used source in the literature to report data on the change in $\mathrm{HbA} 1 \mathrm{c}$ rates associated with the use of CSII compared to MDI was a 2003 meta-analysis, comprising 1,547 patients, and the inclusion criteria were as follows: children, adolescents and / or adults using CSII for a minimum period of 4 weeks for the treatment of T1DM. The results showed a change in glycemic control so that HbA1 was significantly lower after the treatment with CSII (WEISSBERG-BENCHELL et al., 2003). Additionally, another study recently published offered much to think about using insulin pumps in pediatric groups. In this case, the results did not demonstrate clinically significant differences between CSII and MDI in glycemic outcomes, since HbA1c was marginally better in the MDI group (BLAIR et al., 2019).

In this context, several other studies worldwide have assessed the level of HBA1c in adult patients and children using CSII or MDI, such as the survey conducted in France (HAARDT, 1994) with ten adults that suggested $\mathrm{HbA} 1 \mathrm{c} 7.2 \% \pm 0.2$ for CSII vs. $8.5 \% \pm 0.7$ for MDI, corresponding to an improvement of $0.85 \%$ for the patients in using CSII. In Brazil, it was evidenced that during the use of MDI, $14.2 \%$ of patients presented $\mathrm{HbA} 1 \mathrm{c}$ values $<7.5 \%$ vs. $35.71 \%$ using CSII (PETKOVA et al., 2013), demonstrating a better glycemic control with the use of CSII (RIBEIRO, Maria Estela Bellini and DEL ROIO LIBERATORE JUNIOR CUSTODIO and MARTINELLI, 2016).

Several other benefits of using the CSII were described in the manuscripts from United Kingdom (COLQUITT et al., 2004; CUMMINS et al., 2010). In addition to a better control and reduction of fluctuations in glucose and HbA1c levels, the authors found an improvement in the quality of life, including reduced chronic fear of severe hypoglycemia, lifestyle flexibility and participation in social and physical activities and, consequently, health benefits, also extended to the whole family. Hence, the reduction of episodes of severe hypoglycemia produces benefits in three different ways. First, the damage to health is avoided at the time of the episode. Second, the chronic fear of recurrence is relieved. Third, the anxiety due to severe episodes of hypoglycemia is reduced and may allow a lower incidence of diabetes complications, with a more significant decrease on the progression of diabetic retinopathy, end-stage renal disease, and peripheral vascular disease (RIBEIRO, Maria Estela Bellini and DEL ROIO LIBERATORE JUNIOR and CUSTODIO and MARTINELLI, 2016). Therefore, it was found that the therapeutic results are positive after the introduction of CSII and can lead to better long-term outcomes (PETKOVA et al., 2013).

In this way, there are also essential results of scientific research that suggest a considerable gain in QALY, a generic measure of disease burden, including both quality and quantity of life (DONLO et al.., 2006; ROUDIJK et al., 2018). From the perspective of QALY, a study developed in Finland showed CSII appears to be associated with a QALY greater than 0.32 years of life when compared to MDI (8.15 vs.7.83 QALYs, respectively) (Table 2). 
Table 2. Main economic analyzes on the use of continuous subcutaneous insulin infusion (CSII) and Multiple Doses Insulin (MDI) to treat Type one Diabetes Mellitus.

\begin{tabular}{|c|c|c|c|}
\hline & $\begin{array}{c}\text { Continuous } \\
\text { subcutaneous insulin } \\
\text { infusion (CSII) }\end{array}$ & $\begin{array}{l}\text { Multiple doses of } \\
\text { insulin (MDI) }\end{array}$ & Paper \\
\hline \multirow{6}{*}{$\begin{array}{c}\text { Unit quality- } \\
\text { adjusted life- } \\
\text { year } \\
\text { (QALYs) }\end{array}$} & 8.15 & 7.83 & $\begin{array}{l}\text { Cost-Effectiveness of Continuous } \\
\text { Subcutaneous Insulin Infusion Versus } \\
\text { Multiple Daily Injections in Patients with } \\
\text { Poorly Controlled Type } 2 \text { Diabetes in } \\
\text { Finland. Finland, 2019 }\end{array}$ \\
\hline & 1.061 & - & $\begin{array}{l}\text { A cost-effectiveness analysis of } \\
\text { continuous subcutaneous insulin } \\
\text { injection versus multiple daily injections } \\
\text { in type } 1 \text { diabetes patients: A third-party } \\
\text { us payer perspective. EUA, } 2009\end{array}$ \\
\hline & 0.7 & - & $\begin{array}{l}\text { Roze } \mathrm{S} \text {, Smith-Palmer J, Valentine } \mathrm{W} \text {, et } \\
\text { al. Cost-effectiveness of continuous } \\
\text { subcutaneous insulin infusion versus } \\
\text { multiple daily injections of insulin in } \\
\text { Type } 1 \text { diabetes: A systematic review, } \\
2015\end{array}$ \\
\hline & 0.614 & - & $\begin{array}{l}\text { Cost-effectiveness of the use of the } \\
\text { continuous subcutaneous insulin infusion } \\
\text { pump versus daily multiple injections in } \\
\text { type } 1 \text { diabetes adult patients at the } \\
\text { Mexican Institute of Social Security. } \\
\text { Mexican, } 2019\end{array}$ \\
\hline & 10.029 & 9.374 & $\begin{array}{l}\text { Health economic comparison between } \\
\text { continuous subcutaneous insulin infusion } \\
\text { and multiple daily injections of insulin } \\
\text { for the treatment of adult type } 1 \text { diabetes } \\
\text { in Canada. Canada, } 2009\end{array}$ \\
\hline & $7.32 *$ & $6.85 *$ & $\begin{array}{l}\text { The cost-effectiveness of continuous } \\
\text { subcutaneous insulin infusion compared } \\
\text { with multiple daily injections for the } \\
\text { management of diabetes, } 2003 * \text { study } \\
\text { with a Markov model } 10000 \text { patients for } \\
\text { eigth years }\end{array}$ \\
\hline \multirow[t]{2}{*}{$\begin{array}{l}\text { Average CSII } \\
\text { therapy cost }\end{array}$} & US\$ $11940 *$ / patient & US\$ $5085 * /$ patient & $\begin{array}{l}\text { The cost-effectiveness of continuous } \\
\text { subcutaneous insulin infusion compared } \\
\text { with multiple daily injections for the } \\
\text { management of diabetes, } 2003 * \text { study } \\
\text { with a Markov model } 10000 \text { patients for } \\
\text { eigth years }\end{array}$ \\
\hline & \multicolumn{2}{|c|}{ CSII cost $=2.6$ times higher than MDI } & $\begin{array}{l}\text { A Cost-Benefit Comparison of Intensive } \\
\text { Diabetes Management With Implantable }\end{array}$ \\
\hline
\end{tabular}


CSII extra cost of $\$ 2133$ / patient / year

US\$ 54,00
Pumps Versus Multiple Subcutaneous

Injections in Patients With Type I

Diabetes. France, 1994

Clinical effectiveness and cost-

effectiveness of continuous subcutaneous insulin infusion for diabetes: Systematic review and economic evaluation.

England, 2010

Cost-Effectiveness of Continuous

Subcutaneous Insulin Infusion Versus

Multiple Daily Injections in Patients with

Poorly Controlled Type 2 Diabetes in

Finland. Finland, 2019

A cost-effectiveness analysis of

continuous subcutaneous insulin

injection versus multiple daily injections

in type 1 diabetes patients: A third-party

us payer perspective. EUA, 2009

Roze S, Smith-Palmer J, Valentine W, et

al. Cost-effectiveness of continuous

subcutaneous insulin infusion versus

multiple daily injections of insulin in

Type 1 diabetes: A systematic review, 2015
The average total cost of living was US\$ 17,10 higher in the CSII group than in the MDI group (US\$ 149,90 and US $\$ 132,80$, respectively), resulting in a costeffectiveness rate incremental (ICER) of US\$ 54,00 per QALY earned per CSII vs. MDI (ROUDIJK et al., 2018). In the same direction, a study from the United States (CHARLES et al., 2009) showed that CSII was associated with an improvement of 1.061 QALYs vs. MDI for adults (Table 2). ICERs were US\$16,99 per QALY won for CSII vs. MDI in adults.

The cost per QALY in the United Kingdom study was about US\$ 42,80 , and the annual increase in the quality of life of only 0.01 managed to reduce the fear of hypoglycemia over the years of benefit, ultimately reducing the cost from QALY to about US\$32,61 (OLIVEIRA et al., 2018). Moreover, authors (ROZE et al., 2015) corroborate such results by suggesting that the mean gain in QALYs over a lifetime horizon was 0.7 QALYs for adults using CSII (Table 2), resulting in an ICER of US\$ 4,00 per QALY gain.

The economic analysis of the level of $\mathrm{HbA} 1$ carried out in 2013 included 34 children aged 3 to 18 years with T1DM (17 with CSII therapy and 17 with MDI therapy). The study shows that children using CSII manage to maintain stable and on target HbA1c levels, which are preconditions for better diabetes management. Based on these calculations, the cost-effectiveness ratio for the CSII group is US\$1,75, and the group on MDI is US\$ 3,73 (PETKOVA et al., 2013).

In the United Kingdom, an analysis of the costeffectiveness of both therapies showed CSII to be the most lucrative therapy for patients presenting more than two severe hypoglycemic events per year and who required admission to the hospital at least once every year. The cases where CSII might not be economically viable include those related to well-controlled diabetes with few severe hypoglycemic events (SCUFFHAM P and CARR L, 2003).

When the annual pump cost is assumed to be $100 \%$ of the prices observed, the analysis shows that the reduction in HbA1c (for pump compared with MDI) would need to be $12.0 \mathrm{mmol} / \mathrm{mol}(1.1 \%)$ or more, for the pump to have an ICER below US\$25,10 per gained QALY. When the annual cost is $25 \%$ lower, then an $\mathrm{HbA} 1 \mathrm{c}$ reduction of more than $7.7 \mathrm{mmol} / \mathrm{mol}(0.7 \%)$ would be needed to have an ICER below US\$ 250 per gained QALY. When the annual cost is halved, then an $\mathrm{HbA} 1 \mathrm{c}$ reduction of $3.3 \mathrm{mmol} / \mathrm{mol}(0.3 \%)$ would be 
enough to have an ICER below US\$ 25,10 per QALY gained (POLLARD et al., 2018).

In 2019, a group of researchers from Mexico conducted a cost-effectiveness analysis simulating the incidence and progression of complications and nonspecific mortality over the lifetime of a cohort of T1DM adult patients. The average age of the group was 32 years, with diabetes duration of 19 years, an average $\mathrm{HbA} 1 \mathrm{c}$ of $9.2 \% ; 29 \%$ were men. In this study, the use of CSII therapy was associated with an estimated gain of 0.614 QALYs (DOUBOVA et al., 2019) (Table 2). In Canada, an economic health model was used to determine the ICER of the CSII compared to the MDI from a theoretical sample of 1000 adult patients with T1DM. The treatment with CSII was associated with an improvement in discounted life expectancy of 0.655 QALYs over a 60year time horizon, compared with MDI (mean [SD], 10.029 [0.133] vs. 9.374 [0.076] QALYs) (Table 2) (CHARLES et al., 2009).

A study with a Markov model was conducted for to estimate the costs and outcomes for patients treated with CSII compared with MDI (SCUFFHAM P and CAAR L, 2003). The results showed that in eight years the patients could gain 0.48 QALYs using CSII compared to MDI. The additional cost, for this gain in this period, was US $\$ 6,85$. For the 10,000 simulated cases, the average CSII therapy cost was US\$ 11940 per patient, while for MDI, it was US\$ 5085 (Table 2). However, patients using CSII therapy could have, on average, 7.32 QALYs, compared with 6.85 QALYs for MDI (Table 2), showing an additional 0.47 QALYs obtained from CSII. In $0.2 \%$ of cases, CSII was economically feasible, and, in all cases, CSII resulted in greater QALYs. The average additional cost per QALY for CSII was US\$14,40 (CHARLES et al., 2009). In contrast to the results presented above, a survey conducted in France (HAARDT, 1994) showed that the quality of life assessed by diabetes control questionnaires and complications trials was not affected by CSII therapy. However, it is known that this study reported limitations as the need for long-term evaluation of patients, on a larger scale and in a comparative manner.

When the analysis is performed including different brands of equipment, the cost-benefit analyses have shown that the additional cost of CSII compared to MDI varies according to the brand and lifetime of the device, with a value of US\$ 1,36 per year for cheaper equipments ( 8 years of service life) against US $\$ 2,10$ per year for the most expensive model (lifetime of four years). The primary cost of therapy for CSII users is related to consumable items such as infusion sets (tubes, cannulas, catheters), associated with the effective value of the device, and the estimated cost for initial patient training that replaces MDI therapy with CSII, which represents approximately US\$188,27 of this value (PETKOVA et al., 2013). As expected, in France (HAARDT, 1994), a study showed that direct costs, including pump acquisition, implantation, and follow-up of patients, were 2.6 times higher with CSII than with MDI. In England, the use of CSII generates an extra cost of US\$ 2133 per patient per year. In the overall amount, these costs are approximately three times higher than that spent on MDI therapy in Brazil (CUMMINS et al., 2003; SCUFFHAM $P$ and CARR L, 2003). In this perspective, CSII therapy is considered economically viable in the long term because it is compensated for by greater adherence to treatment, better glycemic control, and, consequently, better quality of life, as well as reduction in the cost of treating T1DMrelated complications. Although health technologies are responsible for the more direct medical costs of treating T1DM, they represent a cost-effective treatment option for T1DM (CHARLES et al., 2009; HELLER et al., 2017) because there is a recovery of these expenditures in up to three years (DONLO et al., 2006). Besides, with the use of CSII, the first hypoglycemic event is postponed (HAARDT, 1994).

\section{DISCUSSION}

The CSII is recommended for diabetic children and adolescents, as these patients will spend most of their lives with the disease, so treating it early is extremely urgent. Besides, frequent episodes of severe or asymptomatic hypoglycemia are among the main indications for the use of CSII in this age group. This indication is reinforced by the heterogeneity of results in the reduction of severe hypoglycemia with the use of the MDI regimen, with short and slow insulin analogs (GABBAY M and DIB S, 2007).

In this perspective, considering the cost-benefit ratio of CSII to subgroups, this therapy seems to be useful for patients with specific problems, for example, unsatisfactory glycemic control, unpredictable events of hypoglycemia and glycemic instability in the morning (COLQUITT et al., 2004). For these patients, the CSII could reduce the number of hypoglycemic events and other situations that required hospital treatment in $62.4 \%$ and $68.8 \%$, respectively (HAARDT, 1994). The use of CSII for patients with the adequate disease control (COLQUITT et al., 2004), with few severe hypoglycemic events and well-controlled T1DM, may not be economically feasible (SCUFFHAM P and CARR L, 2003). In the sensitivity analyses carried out in Finland, 
optimistic and pessimistic estimates were performed on a set of variables with an impact on investment return. The results suggested that CSII is more economical in patients with higher baseline HbA1c levels (ROZE et al., 2019). On the other hand, in the United Kingdom, the benefit of the use of CSII therapy is for those who have more than two glycemic severe events per year (17.4 events over eight years) and require hospital treatment at least once every eight months due to hypoglycemia symptoms (SCUFFHAM P and CARR L, 2003).

There are important questions regarding the selection of suitable candidates for CSII therapy, including, for example: will the benefits of continuous subcutaneous insulin infusion outweigh its costs? What will be the results in children treated with pumps from an early age? (LOEWEN and HAAS, 1991). At the same time, CSII therapy has become increasingly popular for the treatment of $\mathrm{T} 1 \mathrm{DM}$ in pediatric patients. At the Children's Hospital Los Angeles Center, United States of American, patients are selected for CSII use through standardized criteria for children and parents, covering medical, educational, and psychological aspects. The National Institute of Health and Clinical Excellence indicates CSII for children under 12 years of age or adults and children over 12 years of age with glycated hemoglobin $(\mathrm{HbA} 1 \mathrm{c})>8.5 \%$ in MDI. On the other hand, the American Diabetes Association suggests that all patients motivated and that take responsibility for their self-control are candidates for the use of the CSII (GRUNBERGER et al., 2014). Table 3 below presents the advantages of the use of CSII compared with MDI.

Table 3. The use of continuous subcutaneous insulin infusion (CSII) in the long term in comparison to Multiple Doses Insulin (MDI) treatment promotes.

\section{Reduction Increase/Beneficial}

$\checkmark$ HbA1 levels

Severe episodes of

hypoglycemia

$\checkmark$ Complications of

T1DM in the long-

term: retinopathy,

nephropathy, ischemic

heart disease, vascular

brain disease and
The number of patients with $\mathrm{HbA} 1$

level of less than $7.5 \%$

$\checkmark$ Quality of Life (Measure by QALY)

$\checkmark \quad$ Lifestyle flexibility

$\checkmark$ Rentability in the long term (ICER

three times less than GDP)

$\checkmark$ Cost (pumps and supplies)

$\checkmark \quad$ The applicability of treatment (specific patient groups)

peripheral vascular.

From this perspective, within the group of people with diabetes indicated for the use of CSII, it is necessary to have a rational decision about the start of treatment. It is after establishing if the benefit conferred by technology is in reasonable proportion to the cost added to the treatment, as wrong decisions may eventually be made in 
practice (MINISTRY OF HEALTH, 2014).

In this regard, actions are being taken in developing countries such as in Brazil and in first world countries intending to have recommendations that fit the necessities and possibilities of each health system. According to the International Society for Pharmacoeconomics and Outcomes Research (ISPOR), 38 countries have their Guidelines (CADTH, 2017). In Brazil, for example, since 2009, there are two tools to support decision making for health system management, and the Ministry of Health also published the Methodological Guidelines for Studies on Economic Assessment of Health Technologies (MINISTRY OF HEALTH, 2014).

Furthermore, epidemiological, and economic studies have already been used in the process of incorporating new technologies into the Brazil's Unified Health System (SUS) (RIBEIRO, Rodrigo Antonini et al., 2017), according to Law No. 12.041 from April 2, 2011 (LUIS et al., 2011).

In this scenario, it is also noticed that Canada, England, Australia, and Poland have adopted epidemiological and economical methods to aid in the allocation of financial resources and budget planning (MARSHALL et al.., 2008; ORLEWSKA and MIERZEJEWSKI, 2004). Some countries have introduced guidelines or legislation to use evaluation for health care (PHARMACEUTICAL BENEFITS ADVISORY COMMITTEE (PBAC) e HEALTH, 2016), in 2018, for example, the National Commission for the Incorporation of Technologies (CONITEC-SUS) developed in Brazil an economic evaluation for the incorporation of health technologies in the treatment of diabetes in the SUS. In this report, a detailed search for evidence in favor of technology, economic analysis, and the budgetary impact was reported, as well as submission to public consultation. At that stage, two electronic forms are available: one for technical-scientific contributions and one for patients or parents or guardians to report their experiences using medicines and/or procedures (MINISTRY OF HEALTH, 2018).

The economic health assessments consider the costs of invested resources and health outcomes, helping in decisions about prioritizing interventions and allocating resources. It is important to emphasize that the studies that make up the economic evaluation have their specific characteristics and limitations and, therefore, the type of research to be used in economic analyses must be justified as to the question to be answered (MINISTRY OF HEALTH, 2014).

Based on the articles selected for the present study, the cost of treatment with CSII is higher than therapy with MDI; however, the clinical benefits that CSII promotes for patients are evident, suggesting a decrease in HbA1c levels, hypoglycemic events, ketoacidosis and improving glycemic control, as well quality of life compared MDI. CSII therapy seems to be beneficial for patients with specific problems, such as poor glycemic control, unpredictable episodes of hypoglycemia, and glycemic instability in the morning.

Thus, treatment outcomes may positively impact patients' health status, public health system, and patient resources. These pieces of evidence suggest that the value invested in the treatment mitigates long-term disease complications. Hence, it can be concluded that the documentation described in the study provides information to support the allocation of financial resources in health care, specifically in the treatment of T1DM, as well as subsidizing decision making regarding the prioritization of actions in public health policy. The study has some limitations. The literature search process did not address all types of existing economic analyzes, and it was not possible to conclude definitively in all areas analyzed that the health gains from CSII therapy are sufficiently substantial concerning the additional costs that the introduction of this technology represents.

\section{REFERENCES}

AMÉRICO, Pedro e ROCHA, Rudi. Subsidizing access to prescription drugs and health outcomes: The case of diabetes. Journal of Health Economics, v. 72, p. 102347, 1 Jul 2020. DOI: 10.1016/j.jhealeco.2020.102347

BECK, Roy W. et al. Advances in technology for management of type 1 diabetes. The Lancet, v. 394, n.
10205 , p. $1265-1273$, 2019. DOI: 10.1016/S01406736(19)31142-0

BLAIR, Joanne C. et al. Continuous subcutaneous insulin infusion versus multiple daily injection regimens in children and young people at diagnosis of type 1 diabetes: Pragmatic randomised controlled trial 
and economic evaluation. BMJ (Online), v. 365, 2019. DOI: $10.1136 / \mathrm{bmj} .11226$

CADTH. Guidelines for the Economic Evaluation of Health Technologies: Canada. Cadth Methods and Guidelines, v. 4, n. March, p. 76, 2017.

CHARLES, Meaghan E.St et al. Health economic comparison between continuous subcutaneous insulin infusion and multiple daily injections of insulin for the treatment of adult type 1 diabetes in Canada. Clinical Therapeutics, v. 31, n. 3, p. 657-667, 2009. DOI: 10.1016/j.clinthera.2009.03.013

COLQUITT, J. L. et al. Clinical and cost-effectiveness of continuous subcutaneous insulin infusion for diabetes. Health Technology Assessment. [S.1.]: National Co-ordinating Centre for HTA. , 2004 DOI: $10.3310 / \mathrm{hta} 8430$

CORTEZ, Daniel Nogueira et al. Complicações e o tempo de diagnóstico do diabetes mellitus na atenção primária. ACTA Paulista de Enfermagem, v. 28, n. 3, p. 250-255, 2015.http://dx.doi.org/10.1590/1982-

CUMMINS, E. et al. Clinical effectiveness and costeffectiveness of continuous subcutaneous insulin infusion for diabetes: Systematic review and economic evaluation. Health Technology Assessment, v. 14, n. 11, p. 1-208, 2010. DOI: 10.3310/hta14110

DAVID, G. et al. Multiple Daily Injection Therapy (MDI) Versus Durable Insulin Pump Therapy in Type II Diabetics: A Breakeven Analysis. Value in Health, v. 15, n. 4, p. A65, 2012. DOI: http://dx.doi.org/10.1016/j.jval.2012.03.359

DONLO, Ignacio Conget et al. Cost-Utility Analysis of Iinsulin Pumps Compared to Multiple Daily doses of Insulin in Patients with Type 1 Diabetes Mellitus in Spain La. p. 679-695, 2006. DOI: doi: 10.1590/s113557272006000600008 .

DOUBOVA, Svetlana V. et al. Cost-effectiveness of the use of the continuous subcutaneous insulin infusion pump versus daily multiple injections in type 1 diabetes adult patients at the Mexican Institute of Social Security. Cost Effectiveness and Resource Allocation, v. $17, \quad$ n. 1, p. 1-12, 2019. DOI: 10.1186/s12962-019-0187-2
GABBAY, Mônica Andrade Lima e DIB, Sérgio A. Comparison between continuous subcutaneous insulin infusion and multiple daily injection regimens in adolescent with type 1 diabetes from a public health care system approach to severe hypoglycemia. Arquivos Brasileiros de Endocrinologia e Metabologia, v. 51, n. 7, p. 1169-1174, 2007. DOI: https://doi.org/10.1590/S0004-27302007000700022.

GOMES, Marilia Brito et al. Does knowledge on diabetes management influence glycemic control? A nationwide study in patients with type 1 diabetes in Brazil. Patient Preference and Adherence, v. 12, p. 53-62, 2018. DOI:10.2147/PPA.S146268

GÓMEZ-DANTÉS, Octavio e FRENK, Julio. Health technology assessment in Mexico. International Journal of Technology Assessment in Health Care, v. 25, n. SUPPL.S1, p. 270-275, 2009. DOI: $10.1017 / \mathrm{S} 0266462309090746$

GRUNBERGER, George et al. Consensus Statement by The American Association of Clinical Encocrinologists/Amarican College of Endocrinology Insulin Management Task Force. AACE/ACE Consensus Statement, v. 20, n. 5, p. 463-489, 2014. DOI: 10.4158/EP14145.PS

HAARDT, Marie Joelle et al. A cost-benefit comparison of intensive diabetes management with implantable pumps versus multiple subcutaneous injections in patients with type I diabetes. Diabetes Care, v. 17, n. 8, p. $847-857,1994$. DOI: $10.2337 /$ diacare. 17.8 .847

HELLER, Simon et al. A cluster randomised trial, costeffectiveness analysis and psychosocial evaluation of insulin pump therapy compared with multiple injections during flexible intensive insulin therapy for type 1 diabetes: The REPOSE Trial. Health Technology Assessment, v. 21, n. 20, p. 1-277, 2017. DOI: $10.3310 /$ hta 21200

IDF. IDF Diabetes Atlas 9th edition 2019.

IEZZI, Elisa e LIPPI BRUNI, Matteo e UGOLINI, Cristina. The role of GP's compensation schemes in diabetes care: Evidence from panel data. Journal of Health Economics, v. 34, n. 1, p. 104-120, 1 Mar 2014. DOI: $10.1016 /$ j.jhealeco.2014.01.002

$\mathrm{KOCH}$, Pedro et al. Health technology assessment in Switzerland. International Journal of Technology 
Assessment in Health Care, v. 25, n. SUPPL.S1, p. 174177, 2009. DOI: $10.1017 /$ S0266462309090606

LOEWEN, S. L. e HAAS, L. B. Complications of diabetes: acute and chronic. Nurse practitioner forum, v. 2, n. 3, p. 181-187, Set 1991.

LUIS, André et al. Análise de Impacto Orçamentário: Manual para o sistema de saúde do Brasil. [S.l: s.n.], 2011.

MARSHALL, Deborah A et al. Guidelines for Conducting Pharmaceutical Budget Impact Analyses for Submission to Public Drug Plans in Canada. PharmacoEconomics, v. 26, n. 6, p. 477-495, 2008. DOI: 10.2165/00019053-200826060-00003

MINISTERIO DA SAUDE. Diretrizes metodológicas: diretriz de avaliação econômica. 2014.

MINISTÉRIO DA SAÚDE. Diretrizes metodológicas: Diretriz de Avaliação Econômica. [S.l: s.n.], 2014.

MINISTÉRIO DA SAÚDE SECRETARIA DE CIÊNCIA, TECNOLOGIA E INSUMOS ESTRATÉGICOS DEPARTAMENTO DE GESTÃO E INCORPORAÇÃO DE TECNOLOGIAS EM SAÚDE COORDENAÇÃO DE AVALIAÇÃO E MONITORAMENTO DE TECNOLOGIAS BrasíliaDF 2018. [S.l: s.n.], [S.d.]. Disponível em: <http://conitec.gov.br/>. Acesso em: 4 jul 2019.

NATHAN, David M. The diabetes control and complications trial/epidemiology of diabetes interventions and complications study at 30 years: Overview. Diabetes Care, v. 37, n. 1, p. 9-16, 2014. DOI: $10.2337 / \mathrm{dc} 13-2112$

NUNES DA SILVA, Everton e SILVA, Marcus Tolentino e GOMES PEREIRA, Maurício. Estudos de avaliação econômica em saúde: definição e aplicabilidade aos sistemas e serviços de saúde Health economic evaluation studies: definition and applicability to health systems and services. Epidemiol. Serv. Saúde, v. 25 , n. 1, p. 205-207, 2016. DOI: https://doi.org/10.5123/s1679-49742016000100023

OLIVEIRA, José Egídio Paulo De e JÚNIOR, Renan Magalhães Montenegro e VENCIO, Sérgio. Diretrizes 2017-2018. [S.1: s.n.], 2018.
ORLEWSKA, Ewa e MIERZEJEWSKI, Piotr. Proposal of Polish Guidelines for Conducting Financial Analysis and Their Comparison to Existing Guidance on Budget Impact in Other Countries. Value in Health, v. 7 , n. 1, p. 1-10, 2004. DOI: 10.1111/j.15244733.2004.71257.x

P, Scuffham e L, Carr. The cost-effectiveness of continuous subcutaneous insulin infusion compared with multiple daily injections for the management of diabetes (Structured abstract). Diabetic Medicine, v. 20, n. 7, p. 586-593, 2003. DOI: 10.1046/j.14645491.2003.00991.x

PETKOVA, Elina et al. Economic evaluation of continuous subcutaneous insulin infusion for children with diabetes - a pilot study: CSII application for children - economic evaluation. BMC Pediatrics, v. 13, n. 1, Out 2013. DOI: $10.1186 / 1471-2431-13-155$

PHARMACEUTICAL BENEFITS ADVISORY COMMITTEE (PBAC) e HEALTH, Australian Government Department of. Guidelines for preparing a submission to the Pharmaceutical Benefits Advisory Committee. n. September, p. 1-205, 2016.

POLLARD, Daniel John et al. Cost-effectiveness of insulin pumps compared with multiple daily injections both provided with structured education for adults with type 1 diabetes: a health economic analysis of the Relative Effectiveness of Pumps over Structured Education (REPOSE) rando. BMJ Open, v. 8, n. 4, 2018. DOI: 10.1136/bmjopen-2017-016766

POZZILLI, Paolo et al. Continuous subcutaneous insulin infusion in diabetes: Patient populations, safety, efficacy, and pharmacoeconomics. Diabetes/Metabolism Research and Reviews. [S.1.]: John Wiley and Sons Ltd. , Jan 2016. DOI: 10.1002/dmrr.2653

RIBEIRO, Maria Estela Bellini e DEL ROIO LIBERATORE JUNIOR, Raphael e CUSTODIO, Rodrigo e MARTINELLI, Carlos Eduardo. Continuous insulin therapy versus multiple insulin injections in the management of type 1 diabetes: A longitutinal study. Revista Paulista de Pediatria, v. 34, n. 1, p. 86-90, 2016. DOI: https://doi.org/10.1016/j.rppede.2015.06.019

RIBEIRO, Maria Estela Bellini e DEL ROIO LIBERATORE JUNIOR, Raphael e CUSTODIO, Rodrigo e MARTINELLI JUNIOR, Carlos Eduardo. 
Insulinoterapia contínua versus múltiplas injeções de insulina no tratamento da diabetes tipo 1: um estudo longitudinal. Revista Paulista de Pediatria, v. 34, n. 1, p. 86-90, 2016.

DOI:

http://dx.doi.org/10.1016/j.rppede.2015.06.019

RIBEIRO, Rodrigo Antonini et al. Diretriz metodológica para estudos de avaliação econômica de tecnologias em saúde no Brasil. Jornal Brasileiro de Economia da Saúde, v. 8, n. 3, p. 174-184, 2017.

ROUDIJK, Bram e DONDERS, A. Rogier T. e STALMEIER, Peep F.M. Setting Dead at Zero: Applying Scale Properties to the QALY Model. Medical Decision Making, v. 38, n. 6, p. 627-634, 2018. DOI: https://doi.org/10.1177/0272989X18765184

ROZE, Stéphane et al. Cost-Effectiveness of Continuous Subcutaneous Insulin Infusion Versus Multiple Daily Injections in Patients with Poorly Controlled Type 2 Diabetes in Finland. Diabetes Therapy, v. 10, n. 2, p. 563-574, 2019. DOI: 10.1007/s13300-019-0575-9. Epub 2019 Feb 7.

ROZE, Stéphane et al. Cost-effectiveness of continuous subcutaneous insulin infusion versus multiple daily injections of insulin in Type 1 diabetes: A systematic review. Diabetic Medicine, v. 32, n. 11, p. 1415-1424, 2015. DOI: DOI: $10.1111 /$ dme. 12792

WEISSBERG-BENCHELL, Jill e ANTISDELLOMAGLIO, Jeanne e SESHADRI, Roopa. Insulin pump therapy: A meta-analysis. Diabetes Care, v. 26, n. 4, p. 1079-1087, 2003. DOI: 10.2337/diacare.26.4.1079 WORLD HEALTH ORGANIZATION. DIABETES. Diabetes. Health Topics.

WORLD HEALTH ORGANIZATION. DIABETES. Diabetes. Health Topics. 